\title{
EMPTY THE MUSEUM, DECOLONIZE THE CURRICULUM, OPEN THEORY
}

\section{Nicholas Mirzoeff}

\begin{abstract}
This essay reviews the possibility of the space of appearance under the authoritarian nationalism that has been ushered in by Brexit and the election of Donald Trump. For those working in and around higher education, I propose that the tasks with which we should begin are: decolonizing the curriculum; emptying the museum; and opening theory. Each of these categories has both a history in past resistance and liberation movements and a present-day dynamic that is explored here from the South African Rhodes Must Fall movement via Occupy Wall Street to the Free University and Antiuniversity.
\end{abstract}

\section{KEYWORDS}

Visual culture, Decolonize, Theory, Space of appearance, Occupy Wall Street, Free University, Rhodes Must Fall

\section{"What time is it on the clock of the world?" \\ Grace Lee Boggs at every meeting she attended}

The clock of the world is showing a new time that we're struggling to understand. ${ }^{1}$ Neo-liberalism became hegemonic in the doubled moment of Thatcher and Reagan coming to power (1979-80). Brexit-Trump heralds a toxic new conjuncture of white supremacy, patriarchy and nationalism. What Stuart Hall called "The Great Moving Right Show" 2 in 1979 has become the "It's Great To Be White Show" in 2016. Hall called Thatcher's regime "authoritarian populism," a mix of force (as manifested in the 1982 Falklands War or the 1984-85 miner's strike) and consent (three election victories in 1979, 1983 and 1987) that combined to produce the hegemonic sense that, in Thatcher's famous phrase, "there is no alternative." The new conjuncture (defined by Hall as "related but distinct contradictions, moving according to very different tempos”) is authoritarian nationalism. It is not premised on consent or hegemony but on the force of white supremacy. Rather than law it relies on order, whether as a political ideology that privileges order over rights, or as a governing strategy that deploys executive orders rather than 
pass legislation. It is not theoretical, but based in aesthetics and desire. The wall will be "beautiful." America will be "great." If Thatcher once cited Hayek and Friedman, Trump sends tweets at 5 a.m. Authoritarian populism lasted thirty years, slowly breaking apart only after the crash of 2007. The "It's Great To Be White Show" is just starting. But already it has lines of force from Latin America (Brazil, Colombia) to Eastern Europe (Poland, Hungary, Bulgaria, Moldova). Modi's India is equally premised on racialized hierarchy. It feels like a global transformation, which will have force for years, perhaps decades.

There is an obvious need to analyze and critique the new conjuncture. But it should not be an imperative to produce new university-based degree programs. Rather, Grace Lee Boggs' injunction for "visionary organizing" is more timely than ever. Perhaps that is the real time on the clock of the world. Such organizing considers how to make a life, more than making a living. It demands that those who can, by which she meant most people in developed societies, live more simply so that others may simply live. For those working in and around higher education, I am going to propose that the tasks with which we might begin are: decolonizing learning; emptying the museum; and opening theory. Let's begin by reminding ourselves that, as Eve Tuck and K. Wayne Yang put it, "decolonization is not a metaphor." 3 It's work in and on the real. The long history of decolonization should be an ample reminder of the possibility of failure in the best of times. Which these are not. How can we bring such understanding into the universities, galleries and museums where many of us work? How can we decolonize these spaces and respond to the challenges of the new conjuncture?

\section{POLITICS IN THE AGE OF AUTHORITARIAN NATIONALISM}

Where does politics happen in these conditions? Hannah Arendt called the domain of politics the "space of appearance." 4 This formation raises many questions. Who has the right to appear? Where? In what time? In what imagined community and lineage? Whose land was it first? What does it look like? While Arendt's phrase is powerful, I want to appropriate and reverse it. Arendt was quite aware that the Greek city state (or polis) she imagined to be the ideal space of appearance was founded on the exclusion of women, children, all non-Greeks, non-citizens and enslaved human beings. It was always and already a space of representation: a space where hierarchy and substitution enables authority and dominance. Only those qualified can even enter the space of representation. Many are still excluded even from the act of voting for representatives 
in the United States (and other representative democracies) including those under 18; past and current "felons"; those without appropriate ID (for example, I had to show ID as a first-time voter in New York); permanent residents; the undocumented; the mentally ill; and so on. Many more are excluded by artful regulations or the material difficulties of voting, such as transport on Native reservations, long waits in minority districts, and so on. Electoral representation isn't working as democracy but it was never intended to do so. As Jacques Rancière has put it, "[o]riginally representation was the exact contrary of democracy." 5 It is instead an "oligarchic form," precisely the mode of governance that is so palpable under global neo-liberalism. David Graeber has shown that the United States is a republic specifically designed to protect its elites against democracy. ${ }^{6}$

What I seek to explore instead of this restricted form is a space of appearance, in which I do not name you but listen so that we create a space of invention and find each other. A space of appearance in which those present claim both what Judith Butler has called the "right to appear" in her re-reading of Arendt ${ }^{7}$ and what I have termed the "right to look." 8 It creates a space for politics and counters representative space. Such spaces are always unequal and uneven for those entering them. In settler colonies, the colonists claim indigenous land by "right" enforced by military power. As Audra Simpson has recently argued, the indigenous do not then try and make the colonists recognize them, or engage with the processes of recognition, but refuse to co-operate with the theft of their lands. ${ }^{9}$ In a ceremony held nearby the Standing Rock protests in December 2016, Chief Leonard Dog Crow accepted an apology from US Army veterans and noted, "we do not own the land, the land owns us." 10 There can be no limit on who appears in these circumstances because it is the land that has sovereignty. But people do not appear commensurately. When Black Lives Matter claims a space of appearance, those who are not Black may appear in the space but need to be aware that it is an uneven space, led by those identifying as Black. For many non-Black allies, this has been a frustrating experience, but that is the measure of how naturalized white supremacy has become. Even the existence of spaces where Black people lead and come first is felt to be threatening by many non-black persons. Any attempt to appear within white supremacy, which is to say, any appearance that is not explicitly and structurally opposed to it, is a claim to hierarchy. A claim to reverse or rearrange that hierarchy must be carefully sustained or it will simply revert to white supremacy. As Alexander Weheliye usefully defines it, "blackness 
designates a changing system of unequal power structures that apportion and delimit which humans can lay claim to full human status and which humans cannot." 11 Those with full human status are those designated "white," a category that is not always correlated to skin pigmentation. Such hierarchies have proved surprisingly resilient because they are not external to capitalism but constitutive of it. That is to say: all capitalism is racial capitalism. ${ }^{12}$ "Race" is not an unfortunate historical legacy of past prejudice or an externality somehow distinct from the class struggle but is rather the vehicle by which the inequality necessary to capitalist accumulation is produced. Or as Hall put it, "race is the modality through which class is lived." Class is a relation to capital, which is inorganic. Commodity fetishism of all kinds tries to persuade us otherwise but it is not so. Race is an imposed relation both to our own bodies and the bodies of others. It is in this way part of lived experience. Popular resistance should begin with that lived experience as a means of destabilizing the lifeless life of capital, rather than the other way around.

\section{THE AUTHORITARIAN SPACE(S) OF REPRESENTATION}

Conventional politics creates a space of representation. Arendt's interpretation of this space consists of multiple interconnected layers, based on the concept that the polis engaged in the market, politics and theatre in the same location. Let's evoke these layers in the current authoritarian nationalist space of representation.

1. Trump's politics are visibly authoritarian, appealing directly to his followers via the Internet and his rally platforms. He disdains law, referring to "so-called judges" and castigating legal restraint on his executive actions as making the US look "weak." He alone is the voice for those he represents, whose only task is to follow him - on Twitter. Even as president-elect, Trump boasted about how many followers he was adding. Perhaps he's aware that while his 24 million followers easily outpace Hillary (11 million), he's far behind Obama's 80 million. As president, his early morning eruptions serve to distract from the dysfunction of his "administration" but also get him into trouble, as with the assertion that President Obama ordered his phones tapped that is in the news at the time of writing. Whereas Mrs. Thatcher was ready for a political struggle both in her own government and against the labor movement, it did not seem to occur to Trump that he would have to actually govern, as opposed to order. If and when there is a crisis requiring state action, his 
weaknesses are likely to be thoroughly revealed. The contradiction between law and order in this new formation may prove critical. It could topple some of the authoritarian regimes, or it may, as in the case of Turkey, provide further impetus to authoritarianism.

2. The ancient market was dependent on enslaved labor so it provided "free" consumption only for a few. By the same token, the "free" trade of the neoliberal era has benefitted the very wealthiest to a quite remarkable degree. As Thomas Piketty has shown, the accumulation of wealth in the top one per cent is comparable only to the gilded age of the 1890s before any form of welfare provision. ${ }^{13}$ Authoritarian nationalism promises ordinary voters symbolic barriers to this inequality in the form of restrictions on immigration, supplemented by canceled trade agreements and tariffs. In this mercantilist world view, a labor shortage will ensue, creating demand for employment. The immigration ban thus gains the nationalists economic legitimacy in the eyes of their supporters, even if inequality as a whole is unchanged. The "good jobs" so often evoked have already been undermined by automation and the assault on trade unions, regardless of low wage competition elsewhere. None of these factors has diminished. The entire enterprise is a spectacular displacement of what is actually needed. The means of production, distribution and exchange need to become sustainable, not to be barricaded. They should be articulated with the palpable demands of the earth system: no more extraction, less plastic, less nitrogen-based fertilizer, a ceiling on carbon dioxide emissions and so on. New forms of counting and accounting will be needed but are nowhere in evidence. Indeed, the Environmental Protection Agency has removed the word "science" from its website and its Secretary believes that additional carbon dioxide in the atmosphere will be beneficial.

3. In the classical theatre, heroes undertake action. Who are heroes? For Aristotle, the hero in Greek tragedy is "one who is highly renowned and prosperous" 14 undergoing events which "strike us as terrible or pitiful". ${ }^{15}$ Trump envisages himself as a tragic hero in the sense that he alone, as he repeatedly said, could save the country from the "terrible" disaster it is in. Of course, he sees no flaw in himself, only others. The tragedy is that of others: "sad!" In the classic theatre, it's the role of the chorus and the audience to see what the hero cannot. In 
the reality TV version now playing, the chorus is composed of scary clowns ${ }^{16}$ and the audience is chanting "Build The Wall." The cinema multiplex has long been full of mutant heroes, as if recognizing a distorted form of Arendt's call for a classical polity in the republic. The mutants' bodies were transformed as a result of an encounter with the chemicals of the military-industrial complex. Those bodies are indeed everywhere from the child miners of the Congo to the lead-poisoned residents of Flint. No superpowers have resulted. More in hope than expectation, the audience shifted its attention from the theatrical space of representation to the political, turning Hillary Clinton into a bad mutant that must be killed. Clinton's image was repeatedly shown placed on a gallows in the period before the election and her name was everywhere greeted with chants of "lock her up." In this imaginary, the election was the "win." By itself, it makes white great again. In his first weeks in office, Trump has insistently returned to the "facts" of his election, falsely claiming that he was denied a majority in the popular vote only by millions of undocumented people voting illegally. One of Trump's few early accomplishments was to set aside regulations that prevented coal mining companies from dumping toxic waste near the point of extraction. The effects of this pollution will be felt most powerfully therefore by those living and working in or near the mines. In the photograph of the ceremony to sign this order, Trump was surrounded by coal miners, who cheered and saluted the return of empowered white men. No one seemed to notice that one of their number was breathing with the aid of an oxygen machine, the plastic tubing discretely entering his nostrils to ward off the effects of black lung, acquired down the mines.

\section{DECOLONIAL AESTHETICS}

As Ta Nehisi Coates has put it, "white supremacy is not merely the work of hotheaded demagogues, or a matter of false consciousness, but a force so fundamental to America that it is difficult to imagine the country without it." 17 There is no need at present for that imaginary. The election was underscored by the question, "do Black Lives Matter?" Its result reaffirms that for the white majority, the answer remains "no." The highly limited space of representation does not at present include Black people, in repudiation of the Obama presidency. The task now, especially for non-Black people who align themselves with anti-anti-blackness is precisely to imagine and create that hitherto non-existent America in which Black 
lives do matter by undermining the force of white supremacy. It's work that has layers in it as well. One place to begin would be to ask how white supremacy makes itself normal and the given against which other actions are judged? In Black Skin, White Masks, Frantz Fanon claimed that cartoons and other forms of popular culture taught (white) people how to be racist. What teaches them/us how to be "white"? Is this not the aesthetic of whiteness? Whiteness demarcates the boundaries of the space of appearance and makes it a space of representation. To be admitted to this space is to not be, or have been, enslaved, or enslaveable. And to be a member of the imperial group, rather than the indigenous. The practical enforcement of this classification and separation was the work of slave law. In 1661, Barbados passed An Act for the Better Ordering and Governing of Negroes, which proclaimed that "all Negroes, Indians, Mulatos or Mestizos" were now to be considered "absolute slaves." That ordering is the reality of settler colonialism, which has not ceased. In the United States, the colonial order has been aestheticized by the myth of its foundation as representing continuity with ancient Greece and Rome. While such concepts might have seemed long past, they are now being circulated as a key meme of "European heritage,” white supremacy's new clothes. ${ }^{18}$ The socalled alt-right racialize Greece and Rome as "Nordic" and white. One such author opines: "There were two racial types in ancient Greece: dark-haired whites and fair-haired whites, as well as gradations in between." 19 He adheres to the overtly-racist (and long discredited) nineteenth-century claim that "fair-haired invaders from the North" were the true ancient Greeks, displacing the darker indigenous population. This account enables the imaginary of an "Aryan" civilization as a chain of connection from classical antiquity to medieval Europe, culminating in the United States. ${ }^{20}$ The extremist Richard B. Spencer, now getting a good deal of media attention, has advocated for "the creation of a white Ethno-State on the North American continent....On one level, it would be a re-constitution of the Roman Empire." 21 That level would be its white supremacy, as evidenced by Spencer's Nazi salute and chant of "Hail Trump" at the so-called National Policy Institute conference in November 2016. Indeed, elite education is still presumed to begin with the ancient classical texts. The latest selective high school in New York City (public schools requiring an examination for admission) is The Brooklyn Latin School. Students not only study Latin, they speak it in school because, the school claims on its website, "the study of Latin grounds our students in the foundational elements of American society.” This classical foundation extends 
across "Western" knowledge from art, to law, museums and even critical theory. White supremacy has persistently been displaced into the centrality of classical learning, which is not accidental as Jacques Derrida pointed out long ago. ${ }^{22}$

In order for it to be possible to begin "see" otherwise, this body of knowledge has to be made to mean otherwise. Let's call this strategy decolonizing, in affiliation with South Africa's "decolonize the curriculum" movement. Students at the University of Cape Town began to protest the prominent presence of a statue of the arch-imperialist Cecil Rhodes on their campus in 2015 using \#RhodesMustFall. After a dynamic campaign, the statue was removed to a museum and the students set about challenging the government's imposition of a tuition increase, a campaign called \#FeesMustFall. When countrywide protests forced the government to back down, some began to engage with national politics and others looked at challenging the very nature of what a university should be. What is central here is that decolonizing is not simply about content but about "hierarchical relations of authority," to borrow a phrase from South African student activist Brian Kamanzi. ${ }^{23}$ As mentioned above, that hierarchy is what has been called "race." It adheres every bit as much to the canonical curriculum as it does to capital. It is not simply a question of revising reading lists, as some popular accounts have had it, to get rid of "white" thinkers. Anthropologist Francis Nyamnjoh points out in his study of \#RhodesMustFall that in South Africa "whiteness, far from being a birthmark, can be acquired and lost with circumstances by whites and blacks alike, regardless of how they define or identify themselves." 24 Accordingly, Kamanzi calls for an institution that "critically engages with the impact of different 'ways of seeing' on the knowledge production process as a whole." That an engineer would use John Berger's famous phrase to engage with the task of decolonizing is striking. From my vantage point, such a way of seeing would be a counter to the aesthetics of white supremacy.

One index of this crisis is the renewed visibility of sexual harassment and assault across UK, US, and South African universities. Decolonise the Curriculum activists have highlighted the prevalence of sexual assault, at Rhodes University and elsewhere. The visual activist artist Zanele Muholi has made the depiction of homophobic and transphobic violence in the South African townships central to her work. The point for many of these activists has been that the South African constitution formally guarantees LGBTQ rights in a forthright fashion. That is to say, representative politics has done what it can but there is no presently-existing space 
of appearance for women, lesbian, gay, queer or trans ${ }^{\star}$ people that is safe. At the time of writing, the South African artist Zwelethu Mthethwa has been found guilty of the murder of Nokupila Moudy Kumalo, a 23 year-old woman, who was a sex worker. Unlike so many hearings relating to Black death in the US, the judge accepted the grainy CCTV footage of Kumalo being kicked to death as a "silent witness." The trial in effect counterposed this CCTV footage with the high-resolution color photographs of Black South Africans living in precarity that brought Mthethwa to fame. Recent accounts of similar violence at UC Berkeley and in the UK university system indicate that this is a systemic manifestation of the current configuration of white supremacy. Mthethwa is of course of Black South African descent, but his situation exemplifies the decolonial definition of "whiteness" as a provisional marker of hierarchy, even in the context of a country once ruled by apartheid. Activists from the Sex Workers Education and Advocacy Taskforce (SWEAT) have been highlighting the case as one of a series of murders and violent assaults against sex workers, whose labor remains criminalized.

In the closing stages of the trial, extended over four years by a variety of maneuvers from Mthethwa's lawyers, one of his works was even exhibited at South Africa's Iziko National Gallery as part of a show called "Our Lady," intended to empower women.25 With over three-quarters of the work in this exhibition being made by male-identified artists, in addition to the Mthethwa scandal, it's clear that much remains to be done. ${ }^{26}$ The Guerilla Girls have documented that leading New York City galleries showed only twenty percent women's work in 2014, slightly up from fifteen percent in 1985 so these problems are systemic to the "art world" as the metonym for global capital that it is. Its transformation will involve rethinking the very goals of the institution. Take museums and critical theory, for example.

\section{THE WHITENESS OF THE MUSEUM}

It's never far to the white marble statues of Greece and Rome from every Western museum entry hall. In the Metropolitan Museum in New York, they are placed in light, high-ceilinged rooms right next to the entrance. African objects, of which the Met has an amazing collection, appear in dark, gloomy spaces. Native American work? One small gallery, which is as far away from the "American" wing as it can physically be. The culture known to us as "Greek" was formed in part from Middle Eastern, Phoenician and Egyptian practices, as Martin Bernal's Black Athena trilogy has shown. ${ }^{27}$ 
Further, the sculptures and buildings of antiquity were so brightly colored in their original form that they look like cartoons to present-day eyes. Sculptor Alan Lequire's reconstruction of the golden Athena Partenos statue by Phidias, once housed in the Parthenon, looks like it would be at home in Donald Trump's apartment. The received classical "whiteness" is a cultural fantasy. This chromatically white whiteness was disseminated by nineteenth-century race science, like that found in Josiah Nott and George Gliddon's Types of Mankind (1854), a pro-slavery, anti-evolution best seller. Their chart showing the presumed difference between chimpanzees, Africans and "Greek" skulls used the classical sculpture known as the Apollo Belvedere to depict the Greek type, as if to acknowledge that no actually existing human could aspire to perfect whiteness. Whiteness has, as it were, two bodies. The often flawed bodies of individual white people, and a magisterial Whiteness that never dies. ${ }^{28}$ White, "negro" and chimpanzee were held by this modality of race science to be entirely separate species, ascending in order of what they called "civilization." Today's museum culture has set aside skin color or species as a means of distinction, of course, but continues unintentionally to evoke the purported continuity of white supremacy by means of its structured ladders of ascending culture. The basic template for Western museums and art galleries ascends from Egypt to Greece, Rome, Italy, France, the United States and culminates in the global contemporary. "Other" cultures are physically marginal within the museum space or addressed in separate buildings.

Italy and Greece have long argued for the restitution of their cultural property, meaning its return to its country or people of origin. That call has been taken up by formerly colonized and indigenous peoples worldwide. One of the most high profile debates has concerned the restitution of the so-called Elgin Marbles, 29 sculptures from Athens' Parthenon, now held in the British Museum, London. When British museum director Neil MacGregor opines, "The Elgin Marbles are no longer part of the story of the Parthenon. They are now part of another story," he admits that the encyclopedic modern museum records the story of colonialism, not that of the locales where the objects were produced. More precisely, a visitor is imbued with the aesthetics of colonialism, in which it is right that such objects are found in imperial capitals. Classical art holds pride of place because its own aesthetic so clearly informs the architectural aesthetic of the museum, whether one considers the British Museum, the Metropolitan Museum or the Altes Museum in Berlin. British classicist Sir John Boardman has said of the claim to 
restitution of the Elgin Marbles: "It would make an appalling precedent and it would ruin any of the major museums of the world." 30 And I reply, "let's start the conversation from that place." Let's ask what would it mean to have a museum complex, now a significant part of the $\$ 60$ billion a year art market, that wasn't about the colonial expropriation of other people's bodies and property? That divested colonial production of materials like cotton and silver and the products of fossil fuels (not just the sponsorships, as in projects like Liberate Tate, although that is a great place to start)? What would be left? Despite Boardman's panic, not all cultural property would be reclaimed, as we can see from the precedent of Native American restitution. Significant sacred objects and human remains have been repatriated but there is no shortage of native cultural work in non-native museums. This pragmatic approach misses the point, however. The real question is: without a colonial aesthetic, however disavowed and displaced it may (or may not) be, what is the logic of display? To whom are objects being shown? To what end?

\section{OPEN THEORY}

The ascending ladder of civilization sacralized in the Western museum finds its corollary in the distinction made by theorist McKenzie Wark between "high" and "low" theory. ${ }^{31}$ "High" theory is hard, philosophy-based, discussed mostly in universities and is mostly the terrain of white people, with obvious and notable exceptions. By contrast, Wark argues, "Low theory is the attempt to think everyday life within practices created in and of and for everyday life, using or misusing high theory to other ends. It happens in collaborative practices that invent their own economies of knowledge." This détournement undermines the "highness" of high theory and its effort to create a hierarchical relation of dominance that rests at base on a certain form of white supremacy. Here, it does not mean simple racism but that the texts one "must" consider begin with Homer and Plato, run via the white Enlightenment to Heidegger and all the French men of recent decades. None of these thinkers were vulgar racists-well, except all the Enlightenment ones. And Heidegger. But the French thinkers so widely studied now were for the most part not racist, except insofar as they ignored race, racism, colonialism and white supremacy, which they mostly did. Only a few, including some of Derrida and Deleuze and Guattari, were anti-racist though. However, détournement can be played both ways. Architect-activist Eyal Weizman has shown how the Israeli Defence Force has appropriated the ideas of Deleuze and Guattari, as well as deconstructive architects like Bernard 
Tschumi, to develop their colonial regime in Palestine. ${ }^{32}$ It is not to the detriment of these thinkers that the IDF used their ideas to come up with the tactic of "walking through walls," meaning breaking a hole in the wall of a Palestinian home when seeking a suspect to gain the advantage of surprise. Only a person devoid of all irony could claim, as the IDF do, that such tactics are "nomadic." Yet "high" theory failed to be resistant to such appropriation: the IDF do not use Fanon. Moreover, it is clear that Palestine is becoming exemplary, rather than exceptional. The Separation Wall has clearly inspired Trump's own wall, which, remember, will be "beautiful.” It is unlikely that even Trump means this literally: he means that white people will perceive their separation from the peoples of Central and South America to be beautiful. In short, it is an aesthetics of white supremacy and colonialism at once.

Just after Wark's book was published, activists in New York began to Occupy Wall Street. Movement participants created a journal called Tidal: Occupy Theory, Occupy Strategy. Published in four print editions and online (no longer active), Tidal placed pieces by leading critical theorists like Gayatri Spivak, Judith Butler and David Graeber next to work by Occupy activists. All writers were enjoined to use "everyday" language, rather than the language of academia. Following Wark's concept, Tidal, like Occupy as a whole, was enacting a (reverse) détournement on the strategies of occupation, including the use of high theory as a method. It deployed the conditions of settler colonialism against itself, from the occupation of "public" space (once segregated by race, now allegedly open to all) to the claim of churches as sanctuaries, not for monks but for anarchists and activists, and the opening of critical theory as a strategy of direct action. Occupy failed on two levels. Its theory of action, based on the Civil Rights Movement strategy of visible suffering causing the state to make concessions, failed to reckon with the power of the police under what Michele Alexander has called "the New Jim Crow." As a result, Occupy Wall Street was summarily evicted on November 15, 2011, some two months after it had set up in Zuccotti Park. That tactical mistake concealed the strategic error of erasing white supremacy under the rubric "we are the 99\%." In relation to the one percent that own capital that was no doubt significant. But it failed to see how the other one percent was the indigenous population; or that the recent precarity of white people had to be set into the context of four centuries of exploitation of African American labor. While a temporary occupation can be a catalyzing tactic, forming what Hakim Bey calls “temporary autonomous zones," occupying theory proved more rhetorical than transformative. 
To make "theory," the work of analysis, do anti-racist work, it has to be open, which is to say, anti-occupation, whether in Palestine or the United States. Indigenous people creating a camp at Standing Rock are not occupying. They are at home. Or more exactly, they are in open space because they do not claim to own the land but to be owned by it. For those divided by the color line superimposed over such open space, the "open" in "open theory" is a verb and an imperative. It has to begin by acknowledging that the anti-racist and decolonial work that has been done in and around universities in North America and Britain in particular, but across the West in general, has to some degree failed. If it had not, the return of authoritarian nationalism might not have happened. The GI Bill and the Beveridge Report enshrined the university degree as a key component of the post-Second World War settlement. Neo-liberalism's first wave undermined much of that settlement and its new formation appears ready to set it aside altogether in favor of a focus on STEM (Science, Technology, Engineering and Mathematics) degrees and short-term vocational courses. Trump has proposed abolishing the National Endowment for the Arts and the National Endowment for the Humanities, while UK officials no longer fund degrees in the humanities, which rely on tuition revenue to survive.

These changes are indicative of a systemic collapse in the hegemonic post-war concept of the social, precisely as intended by Thatcher, mirrored by the ongoing implosion of social democratic parties. Majorities of white people in the US and the UK, and significant minorities of whites in other Western countries no longer accept the anti-racist formation of the social. That is a politer way to say that they do not accept people of color and indigenous populations as belonging to their society, so they have attempted to displace the concept of society with that of race. Race is deployed as a nation of culturally and ethnically homogenous individuals, who accept the need for strong leadership as the means of coherence in everyday life. Leading political figures from the UK Foreign Secretary Boris Johnson ${ }^{33}$ to Helen Zille (Premier of the Western Cape, one of South Africa's nine provinces, and former leader of the country's second largest political party, the Democratic Alliance) have further claimed that colonialism had positive and "valuable aspects." ${ }^{44}$ For if colonial-style rule is to be re-imposed, it cannot be considered inherently corrupt or negative. Remember that Fanon defined fascism as the application of colonialism to the colonizer's home nation.

From the point of view of decolonizing the curriculum, these are also failings of the education system. As the Kenyan student 
activist Njoki Wamai points out, British colonialism is not even discussed in UK primary and secondary schools. ${ }^{35}$ In fact, the present UK government appears to moving in the direction of teaching colonialism as a positive virtue. Alternative formats for learning have emerged from social movements, in active reprise of $1960 \mathrm{~s}$ decolonial tactics, including the Free University of New York City and the UK-based Antiuniversity. Free University was founded in 1965 , charging a low tuition but open in terms of what might be taught and how. In their catalogue, the Free University declared, "American universities have been reduced to institutions of intellectual servitude...in harmony with the military and industrial leadership of our society.” In 1965 it offered twenty-five courses, including one taught by the artist Carolee Schneeman and some 210 people enrolled. Psychotherapist Joseph Berke, who participated in Free U, helped bring the concept to London, where it was called the Antiuniversity, founded in 1967. Its participants included R.D. Laing, Juliet Mitchell and later Stuart Hall, reflecting its unusual alliance of antipsychiatry and the New Left Review. The Free University saw its project as being directly connected to the Black liberation movement, although most of its participants were white. The organizers of Antiuniversity group brought Stokely Carmichael to speak on Black Power in London at their 1967 Dialectics of Liberation event. Perhaps as a result, Obi Egbuna, leader of the United Colored People Association, led a discussion of the same name at the 1968 Antiuniversity, advertised with a reprinted letter from prison by Rap Brown. Stuart Hall offered an event called "Communications," while CLR James, the author of The Black Jacobins, was listed as visiting faculty, along with Carmichael, and Allen Ginsberg. Carolee Schneeman offered a month long intensive beginning in May 1968. Ruth First, the South African activist, offered a course on the anti-apartheid struggle, while Robin Blackburn and Alexander Krasso proposed a study of the Cuban revolution. There were classes on Maoism, socialism in Asia and ancient India and expressions of solidarity with Vietnam. Three hundred people took part. Both Free University and Antiuniversity saw themselves as part of an alternative global "underground" of alternative study that would produce what they called "cultural guerilla warfare" in solidarity with what was then called the "third world." 36

The 1960s projects crumbled in the usual way of the period. Both have been revived recently. Free University was part of the Occupy movement, seeing itself as a radical, movement-based open learning environment. Its first event was held in Madison 
Square Park on MayDay 2012 as part of the General Strike called that day by OWS, immigrant groups and trade unions. There was an open call for participation, resulting in everything from "Occupy Algebra," to performances of the anarchist play Can't Pay, Won't Pay and guest lectures by people such as David Harvey and Andrew Ross. Most sessions, though, were led by a group and featured quiet and extensive discussion around a park bench or on the grass. Free University continues to be active and has held numerous events, including an Anti-Trump Free School just before the inauguration in January 2017. Based primarily in New York City, Free University builds on the legacies of Occupy to create, in their own words: "an experiment in radical education and an attempt to create education as it ought to be, building on the historic tradition of movement freedom schools. Our project is born out of a recognition that the current system of higher education is as unequal as it is unsustainable, while vast sources of knowledge across communities are all-too-hidden and undervalued." 37 The Antiuniversity is now active again across the UK. Like Free University, it has specific events and festivals, rather than trying to offer ongoing courses. It is open to anyone that wants to offer a course and its offerings tend to be a little more eclectic than Free University. In addition to the political events, there are sessions called "Fuck it, let's make a band," Breaditation and even magic. Antiuniversity is often engaged with archives and walking as a form of research, whereas Free University is more in dialogue with social movements.

These are small differences and the similarities are more important. In the 1960s, these projects were attempts to create alternative institutions that felt themselves to be part of a rising tide of revolution. Today, the groups operate more like social movements, holding actions and creating networks, but unable to find the kind of permanent space that was often available in both London and New York in the 1960s. In the crisis of this new conjuncture, what should alternative learning and open theory try to do? Previously, there has been a skeptical relationship to formal institutions of education. With resources so scarce, it might be time to revisit Fred Moten and Stephano Harney's injunction to both steal from the university and use it as a refuge. The theft is what de Certeau called poaching - using photocopiers, computers, software and meeting space without paying. The refuge is no longer a metaphor, because nationalist regimes are looking to deport and detain international students, especially those from so-called Islamic countries. Free University and Antiuniversity have operated locally. With the resurgence of decolonial thought and practice in Africa, it must be time 
to think about how to work in global networks. In this perspective, learning is life-long, based on experience as much as qualifications, and open to all. It would require a space where you're willing to look at the challenge of making the new without hierarchy, without preconditions and without any guarantees. It is a global challenge. It's not a question of throwing out art objects but of creating a space that embraces the necessity of decolonization. I want an institution - whether university, museum, gallery or whatever - that doesn't reproduce white supremacy, that doesn't represent a prison, in which there isn't expropriated labor, there isn't extinction, and there isn't genocide. What would that look like?

\section{NOTES}

1 This piece is based on two blog posts from a series called "Spaces of Appearance" that I undertook for the Foto Museum, Winterthur around the time of the US presidential election. I have sought to develop and expand the argument somewhat, while retaining the direct address of the blog style. Many thanks to Doris Gassert at the Foto Museum for directing the series, which can be found at: https://www.fotomuseum.ch/en/explore/still-searching/ series/29437_the_spaces_of_appearance

2 Stuart Hall, "The Great Moving Right Show," Marxism Today (January 1979): 14-19.

3 Eve Tuck and K. Wayne Yang, "Decolonization Is Not A Metaphor," Decolonization: Indigeneity, Education \&Society, Vol. 1, No.1 (2012): 1-40.

4 Hannah Arendt, The Human Condition, introduction by Margaret Canovan, 2nd ed. (Chicago: University of Chicago Press, [1958], 1998), 199.

5 Jacques Rancière, Hatred of Democracy (New York: Verso, 2009), 53.

6 David Graeber, The Democracy Project: A History, a Crisis, a Movement (New York: Allen Lane, 2013).

7 Judith Butler, Notes on a Performative Theory of Assembly (Berkeley: University of California Press, 2015), 26.

8 "The right to look is not about seeing. It begins at the personal level with the look into someone else's eyes to express friendship, solidarity, or love. That look must be mutual, each person inventing the other or it fails. As such it is unrepresentable. The right to look claims autonomy, not individualism or voyeurism, but the claim to a political subjectivity and collectivity, Nicholas Mirzoeff, "The right to look. The invention of the other," The Right to Look: A Counter-history of Visuality (Durham: Duke University Press, 2011), 1.

9 Audra Simpson, Mohawk Interruptus: Political Life Across the Borders of Settler States (Durham: Duke University Press, 2014), 20-22

10 Jenna Amatulli, "Forgiveness Ceremony Unites Veterans And Natives At Standing Rock Casino," (December 6, 2016), Huffington Post, http://www. huffingtonpost.com/entry/forgiveness-ceremonyunites-veterans-and-natives-at-standing-rock-casino_ us_5845cdbbe4b055b31398b199
11 Alexander G. Weheliye, Habeas Viscus: Racializing Assemblages, Biopolitics, and Black Feminist Theories of the Human (Durham: Duke University Press, 2014), 3.

12 See Cedric J. Robinson, Black Marxism: The Making of the Black Radical Tradition (Chapel Hill: University of North Carolina Press, 2000).

13 Thomas Piketty, Capital in the Twenty-First Century (Cambridge, MA: Harvard University Press, 2013).

14 Aristotle, Poetics I, 6.

15 Op.cit., 14.

16 See Mirzoeff, "MAGA Masculinity, Scary Clowns and the Souls of White Folk," (November 1, 2016), https:// www.fotomuseum.ch/en/explore/still-searching/ articles/29438_maga_masculinity_scary_clowns_and_ the_souls_of_white_folk.

17 Ta Nahesi Coates, "The Case for Reparations," The Atlantic (June 4, 2014) http://www.theatlantic.com/magazine/ archive/2014/06/the-case-for-reparations/361631/

18 Michael Knowles, "An Actual Conservative's Guide to the Alt-Right," The Daily Wire (September 26, 2016). http:// www.dailywire.com/news/9441/actual-conservativesguide-alt-right-8-things-you-michael-knowles

19 Jon Harrison Sims, "What Race Were the Greeks and Romans?" The Unz Review (October 1, 2010). http://www.unz.com/article/ what-race-were-the-greeks-and-romans/

20 Auld Wat, "Spirit of the Occident," WCR (July 25, 2016). https://westcoastrxers.com/2016/07/25/ spirit-of-the-occident/

21 Richard Spencer, "Exiled," Radix (July 14, 2016), http:// www.radixjournal.com/journal/2016/7/14/exiled

22 Jacques Derrida, "White Mythology: Metaphor in the Text of Philosophy, " trans. F. C. T. Moore, New Literary History, Vol. 6, No. 1 (Autumn, 1974): 5-7

23 Brian Kamanzi,"Decolonising the curriculum," The Daily Maverick http://www.dailymaverick.co.za/ opinionista/2016-04-28-decolonising-the-curriculumthe-silent-war-for-tomorrow/\#.WDMuK5MrKuU

24 Francis B. Nyamnjoh, \#RhodesMustFall: Nibbling at Resilient Colonialism in South Africa (Bamenda, Cameroon: Langaa Research and Publishing, 2016), 7. 
25 http://citizen.co.za/news/news-national/1359847/ take-down-murder-accused-mthethwas-artwork-sweat/

26 https://www.dailymaverick.co.za/article/2017-0118-art-and-outrage-national-gallery-under-attack/\#. WMwIT7YrKuU

27 Martin Bernal, Black Athena: The Afroasiatic Roots of Classical Civilization, 3 vols. (New Brunswick: Rutgers University Press, 1987-2006).

28 Here I am parodying the terminology of Ernst Kantorowicz's classic The King's Two Bodies: A Study in Mediaeval [sic] Political Theology (Princeton: Princeton University Press, 1957).

29 For the Greek government position, see http://odysseus. culture.gr/a/1/12/ea121.html

30 http://www.telegraph.co.uk/culture/ culturenews/11152649/Return-of-Elgin-Marbleswould-ruin-museums-warns-leading-historian.html

31 Chris Webb, "Long live low theory! - McKenzie Wark on the legacy and continued relevance of Situationism," Verso Blog (September 5, 2011), http://www.versobooks. com/blogs/690-long-live-low-theory-mckenziewark-on-the-legacy-and-continued-relevance-ofsituationism

32 Eyal Weizman, Hollow Land: Israel's Architecture of Occupation (New York: Verso, 2007), 212.

33 https://blogs.spectator.co.uk/2016/07/ boris-archive-africa-mess-cant-blame-colonialism/

34 Vito Laterza, "We are all Helen Zille. Or, why the West thinks that colonialism was not all bad," Africa Is $A$ Country (March 16, 2017), http://africasacountry. com/2017/03/we-are-all-helen-zille-or-why-the-westthinks-that-colonialism-was-not-all-bad/

35 Njoki Wamai, "Decolonising the academy - Towards a global movement?"

University World News (27 May 2016) issue 415, http://www.universityworldnews.com/article. php?story=20160524135416842

36 Information on Free University and Antiuniversity was taken from the reprint of the original documents in Jakob Jakobsen (ed.), ,Antiuniversity of London Antihistory Tabloid (Antiuniversity, 2013), np.

37 http://freeuniversitynyc.org/ 